\title{
Introduction: Ethnography, Performance and Imagination
}

\author{
Magdalena Kazubowski-Houston York University \\ Virginie Magnat University of British Columbia
}

\begin{abstract}
This introduction to the thematic section entitled "Ethnography, Performance and Imagination" explores performance as "imaginative ethnography" (Elliott and Culhane 2017), a transdisciplinary, collaborative, embodied, critical and engaged research practice that draws from anthropology and the creative arts. In particular, it focuses on the performativity of performance (an event intentionally staged for an audience) employed as both an ethnographic process (fieldwork) and a mode of ethnographic representation. It asks: can performance help us research and better understand imaginative lifeworlds as they unfold in the present moment? Can performance potentially assist us in re-envisioning what an anthropology of imagination might look like? It also inquires whether working at the intersections of anthropology, ethnography, performance and imagination could transform how we attend to ethnographic processes and products, questions of reflexivity and representation, ethnographer-participant relations and ethnographic audiences. It considers how performance employed as ethnography might help us reconceptualise public engagement and ethnographic activism, collaborative/participatory ethnography and interdisciplinary research within and beyond the academy. Finally, this introduction provides a brief overview of the contributions to this thematic section, which address these questions from a variety of theoretical, methodological and topical standpoints.
\end{abstract}

Résumé : Cette Introduction à la section thématique « Ethnographie, performance et imagination » explore la performance comme " ethnographie imaginative » (Elliott et Culhane 2017), c'est-à-dire comme pratique de recherche transdisciplinaire, collaborative, incarnée, critique et engagée qui s'inspire de l'anthropologie et des arts créatifs. Laccent est mis en particulier sur la performativité de la performance (un événement délibérément mis en scène pour un public), employée à la fois comme processus ethnographique (travail de terrain) et comme mode de représentation ethnographique. Les questions posées sont les suivantes : La performance peut-elle nous aider à étudier et à mieux comprendre les mondes imaginaires tels qu'ils se déploient dans le moment présent ? La performance nous permet-elle de repenser l'anthropologie de l'imagination ? Est également posée la question de savoir si le travail mené à la croisée de l'anthropologie, de l'ethnographie, de la performance et de l'imagination permet de transformer la façon dont sont abordés les processus et les produits ethnographiques, les questions de réflexivité et de représentation, les relations ethnographes-participants et les publics ethnographiques. La manière dont la performance employée comme ethnographie peut nous aider à reconceptualiser l'engagement public et l'activisme ethnographique, l'ethnographie collaborative/participante, ainsi que la recherche interdisciplinaire au sein et au-delà du monde universitaire, est aussi examinée. Enfin, cette Introduction donne un bref aperçu des contributions à cette section thématique, lesquelles abordent ces questions de différents points de vue théoriques, méthodologiques et thématiques.

\section{Introduction}

Randia: (Why do you do plays? You are an

Randia, an elderly Romani woman and the long-time interlocutor of Magdalena Kazubowski-Houston (Magda), posed this question following a dramatic storytelling session in which she narrated a play script based on her life experiences. More than a recitation of lines, this session involved full-fledged acting in which Randia and Magda assumed the roles of different characters. In that particular session, Randia, playing Córka, confided in her friend Ela (played by Magda) that, in the past few weeks, she had been having nightly visitations from apparitions. She explained that the apparitions, while not always easily identifiable, frequently resembled her deceased relatives, especially her late daughter and son. Subsequently, Córka sought Ela's counsel on how to respond to these apparitions, and Randia (as Córka) instructed Magda (as Ela) to respond that Córka should "just talk to them" and "let them listen." Córka, enthralled at this thought, began breathlessly blurting out all the things she could tell the spirits: that she misses them, that she is not afraid of them, that her children had left her and rarely visit, that she is scared of loneliness and of dying alone, and that she hopes they will protect her in the moment of her own death.

A few minutes later, Randia stepped out of character and addressed Magda as Magda:

See ... all these thoughts sit like stone in me ... I've no one to talk to ... but who would I tell all these things to anyways? .. . "Stupid old baba," they would 
say. That's all. But when I sit here and do the play ... the things I wouldn't have imagined before . . . so, so it's good you come. My daughter also comes ... the one who died last year ... she listens ... and now when I've buried my son, he'll come too.

With this statement, Randia clearly established an affinity between her character Córka and herself. Like Córka, she too had lost two of her children, whose spirits now visited her. Her statement also seemed to imply that she was grateful for the storytelling sessions, for the ability to express the "thoughts that sit like stone in [her]," or to do "the things [she] wouldn't have imagined before." Yet only a few minutes later, she nonchalantly asked, "Why do you do plays? You are an anthropologist!" Randia's earlier expression of gratitude for the storytelling process lies in tension with this question, which seems to query the usefulness of it.

In this thematic section, we explore why imaginative approaches and methodologies - dramatic storytelling, for instance - are gaining cachet in anthropology and cognate disciplines. Our interlocutors might appreciate such creative research processes, and so might we, but why are such processes worthwhile? What do they afford our interlocutors and the larger anthropological project? The contributors to this thematic section address these questions from a variety of theoretical, methodological and topical standpoints. Their articles here can be situated in the context of the emergent "imaginative ethnography" (Elliott and Culhane 2017) scholarship that takes imagination as central to social life, lived experience, anthropological study and ethnographic research. Most of us are affiliated, in one way or another, with the Centre for Imaginative Ethnography (http://imaginativeethnography.org/), a transnational cyber-collective committed to engaging in critical, embodied, reflexive and collaborative ethnographic practices that draw on anthropology, ethnography and the creative arts.

This thematic section specifically explores performance both as an anthropological approach in the study of imagination and as an imaginative ethnographic methodology. Here, we pay attention to performance and to performativity. Although the line between the two is blurry, and the terms have been frequently used interchangeably in anthropology and related fields, we do not perceive them as isomorphic (Murray 2016, 62). Performance can be conceptualised as an event intentionally staged for an audience, in either a traditional theatre venue and/or a public space. Performativity draws on, among other things, Erving Goffman's (1959) idea of "the presentation of self in everyday life"; Marcel Mauss's (1973 [1935]) consideration of bodily movements, gestures and expressions as enactments of the social; J.L. Austin's (1962) notion of performative utterances as constituting subjects; and Judith Butler's (1990, 25; 1995, 198) articulation of gender as citational enactments of discourse that produce, subvert and discipline gendered identity. The contributors to this thematic section focus not so much on the performativity of everyday practices, which can be attended to by more conventional forms of participant observation, but rather on the performativity of performance (an event intentionally staged for an audience) employed as both an ethnographic process (fieldwork) and a mode of ethnographic representation. The articles presented here consider staged performance (how it produces ethnographic knowledge) and its performativity (how it enacts and subverts identity, [inter]subjectivity, and power) as new "routes to knowing" (Hogan and Pink 2010, 158) and how "imaginative lifeworlds" (Irving 2011, 22) are made and unmade, lived and expressed in everyday contexts.

We understand imaginative lifeworlds to be the diverse, messy, shifting, incidental, improvisational and generative intersubjective experiences, practices and processes that constitute and are constituted by people's inner and outer lives, individuality and sociability, agency and constraint, and ethnographer-interlocutor relations. Can performance help us research and better understand such imaginative lifeworlds as they unfold in the present moment? What can performance do that other more conventional anthropological approaches and methods might not? Can performance potentially assist us in re-envisioning what an anthropology of imagination might look like? These contributions also explore performance as "imaginative ethnography" (Elliott and Culhane 2017), a transdisciplinary, collaborative, embodied, critical and engaged research practice that draws from anthropology and the creative arts. The contributors to this thematic section inquire into whether working at the intersections of anthropology, ethnography, performance and imagination could transform how we attend to ethnographic processes and products, questions of reflexivity and representation, ethnographer-participant relations and ethnographic audiences. In their articles, they also consider whether performance employed as ethnography could help us reconceptualise public engagement and ethnographic activism, collaborative/participatory ethnography, and interdisciplinary research within and beyond the academy.

\section{Imagination}

What is imagination, and why is it significant to the anthropological project? And what is it about imagination that may render it particularly conducive to be studied by means of performance? 
In anthropology, until quite recently, imagination has been viewed with distrust - likely due to its association with subjectivity and individual interior states, which stand in sharp contrast to the discipline's preoccupation with the social and the material (McLean 2007, 5; Robbins 2010, 306). However, as part of anthropology's growing dissatisfaction with the concept of culture, there has been a tendency to substitute imagination for culture, where a social imaginary is viewed as a set of meanings and understandings (Sneath, Holbraad and Pederson 2009, 8; Taylor 2002, 106). Imagination has also been frequently perceived in instrumental terms, as serving some sort of purpose - for example, as a community-making process (Anderson 2016 [1983]; Sneath, Holbraad and Pederson 2009, 8). Furthermore, nineteenth-century Romantic understandings of imagination as largely positive and creative - the Dionysian and Promethean forces (Friedrich 2007, 14; Sneath, Holbraad and Pederson 2009, 10) - have shaped anthropological ideas about imagination. For example, Vincent Crapanzano (2004, 19), who sees imagination as allowing us 'to project our 'fables' in a direction that does not have to reckon with the "evident universe," falls within this tradition. Similarly, Arjun Appadurai $(1996,53)$ argues that in the era of globalisation, "the imagination has now acquired a singular new power in social life" and constitutes "a space of contestation in which individuals and groups seek to annex the global into their own practices of the modern" (4). For Appadurai, collective imagination can become "a staging ground for action, and not only for escape" (7). And for Jean and John Comaroff (1999, 8), it is "civil society [that] serves as a tool of the social imagination."

This positive view has a tendency to associate imagination with a certain degree of freedom, evident, for example, in Crapanzano's (2004) notion of "imaginative horizons" that can reach beyond the real (although he does recognise the delusional tendency of freedom). Similarly, Nigel Rapport and Joanna Overing (2000), in line with Sartre, define imagination as an activity through which individuals make and remake their past, present and future selves by freeing themselves from reality and its constraints. Imagination thus affords us freedom and affords our lives "an emergent quality" (Rapport and Overing 2000,4). Others have conceptualised imagination as an "engine of newness" that "knows no barriers" and that can "formulate the world as it wants" (Robbins 2010, 305-306). Referring to the work of Slovenian psychoanalytic philosopher Slavoj Žižek, Joel Robbins (2010, 307, 310) suggests that the power of imagination lies in its ability to obliterate the real world it encounters through perception and replace it with an alternate one. There are also approaches that draw on phenomenological notions of imagination, specifically those concerned with embodiment (Csordas 1994). Such perspectives see imagination as inextricably linked to experience and perception (McLean 2007, 6). Brian Massumi (2002, 134), for example, suggests that imagination is a "thinking feeling . . . the mutual development of thought and sensation, as they arrive together, pre-what they will have become, just beginning to unfold from the unfelt and unthinkable outside: of process, transformation in itself."

Finally, some of the most recent approaches - building on Kant's understanding of imagination as pervasive and processual - have pushed anthropological thinking about imagination in new directions. These approaches consider imagination an outcome rather than a condition and focus on the "technologies of the imagination" that generate, without determining, such outcomes (Sneath, Holbraad and Pederson 2009, 19). This view holds that the technologies of the imagination "'afford' imaginings in ways that, though hardly random, are nevertheless essentially unpredictable and often quite unintended" (22). Seeing ethnography as "a technology of the anthropologist's analytical imagination" (25), this perspective holds that ethnography's attention to the peculiarities of the everyday is indispensable for researching and analysing the workings of technologies of the imagination. A special issue of the Irish Journal of Anthropology, co-edited by Stuart McLean and Steve Coleman, puts forth other interesting perspectives on imagination. For example, McLean $(2007,8)$ views imagination as an intersubjective space between the human and the non-human, while Paul Friedrich $(2007,12)$ sees it as "the whole realm of the contingent and the possible in the individual and cultural imagination." Friedrich is interested in how "imaginative infinitudes" extend into interior worlds, while at the same time always being constrained "by direct or indirect experience" (11-12); he sees the methodological advantage of imagination in its fluid, dynamic and processual qualities. Kirsten Hastrup (2007, 28), on the other hand, suggests that individuals employ imagination in order to take action, because "the present is always inconclusive, and to act meaningfully, one has to imaginatively project oneself into the future." However, she recognises that the agency of imagination cannot be viewed as intentional because it is always contingent even if not determined (32). While she holds imagination to be individual, Hastrup also stresses its dialogic capacity.

Drawing on the aforementioned anthropological approaches to imagination, the contributors to this thematic section engage with imagination as an integral component of human consciousness - an intersubjective capacity inextricably interconnected with embodied 
experience, expression, perception, cognition and emotion - that is constitutive of and constituted by the material world. While we see imagination as firmly grounded in the real, we are inspired by its potentiality to subvert and remake the existing world - a view shared by Crapanzano (2004), Rapport and Overing (2000), and Robbins (2010). We also take seriously imagination's capacity as a "ground for action" (Appadurai 1996, 7) from which to venture into the future (Hastrup 2007, 28) and that imagination is a space between the self and not-self (Sime 2007, 48) that can open up possibilities for different experiences and imaginaries. Ultimately, however aligning with those who treat imagination as an outcome rather than a condition (Sneath, Holbraad and Pederson 2009) - we are less concerned with defining imagination as a conceptual category and more with attending to it as an emergent, dynamic and shifting process, action and exterior mode of being and expression. Here, imagination, rather than being sui generis, always depends on a particular perspective and interpretation, as it capriciously plays itself out between intent and outcome, freedom and constraint, hegemony and resistance, private and public, and real and fantastical. First and foremost, we track imagination as it emerges close to the ground in the field, focusing on the stories people tell us and how they tell these stories (through actions, gestures, movements, speech etc.), how they live and enact these stories in their everyday lives, and how their everyday lives are lived and enacted in these stories.

At the same time, however, the contributors to this thematic section share a common view that imagination poses certain ontological, epistemological and methodological challenges to its anthropological and ethnographic study. Because people's lifeworlds can sometimes be too painful, personal, unacknowledged or buried to study through conventional ethnographic methods - which largely rely on observation and verbal expression - more metaphoric, imaginative, embodied and performative modes of knowledge construction might at times be required. While a few anthropologists have begun experimenting with ways of studying people's imaginative lifeworlds (Elliott and Culhane 2017; Hogan and Pink 2010; Irving 2011; Kazubowski-Houston 2017a, 2017b; Kumar 2013), there has been little consideration, either theoretical or methodological, of how to study imagination anthropologically. The contributors to this section ask the following questions: How might we interpret and represent fluid, shifting and dynamic imaginative lifeworlds? If conventional ethnographic methods are too static, how might we rethink our approaches? Can performance employed as an anthropological approach and ethnographic method assist in this process?
Which of its attributes might prove particularly useful in the anthropological study of imagination?

\section{Performance}

Anthropological interest in performance has a long history and has formed largely at the interdisciplinary junctures of humanities and social sciences. Contemporary anthropologists recognise performance's "emergence" - the fluid, shifting, dynamic and improvisational processes of making and remaking in and through the interactions between and among "performers" and audiences - as its significant defining quality (Korom 2013, 2; Lord 2000). Bronislaw Malinowski (1948, 82) acknowledged this emergent quality of performance when he argued that performances could not be merely described with words without accounting for their various contexts, physical expressions and audiences. While the focus on performance in its context had, to a certain extent, become important to the theorists of performance in the 1950s and 1960s (e.g., Singer 1961, 1972), these early approaches predominantly analysed performance as a formal, patterned and stereotypical ritual action; its interchange of form and content/meaning; and its function or relation to social structure (Durkheim 1965 [1915]; Gennep 1960; Turner 1967).

Not until the emergence of the "ethnography of communications" in the 1970s did the contextual approach to the study of performance take centre stage (Bauman and Sherzer 1974; Ben-Amos and Goldstein 1975; Hymes 1964, 1975). Interest in the contextual study of performance and the performative dimensions of everyday life subsequently materialised in the emergence of a distinct field - performance studies - in the 1980s with the work of Victor Turner $(1982,1986)$ and performance theorist Richard Schechner (1985). In The Anthropology of Performance, Turner (1988) distinguishes his perspective from Goffman's view that the world is a theatre, as well as from Schechner's contention that there is a connection between social drama and theatre. Turner argues instead that social drama results from the suspension of normative role-playing and posits that if everyday life is theatre, then social drama is metatheatre. In "Dewey, Dilthey, and Drama: An Essay in the Anthropology of Experience," Turner $(1986,41)$ observes that the liminal phase of rituals, which in his definition of social drama constitutes the third phase in the "breach, crisis, redress, reintegration, or schism" sequence, is characterised by the presence of ambiguous identities, monstrous images, ordeals, esoteric and paradoxical instructions, symbolic types such as maskers and clowns, gender reversals, anonymity and so on. These elements, often combined in ritual practices, pertain to what he identifies as the 
subjunctive, liminal mood of performance. Interpretive anthropology, in turn, concerned with the search for meaning rather than law (Geertz 1973), viewed ritual and performance as part of the significant symbols that compose social life, open to perpetual interpretation and reinterpretation.

The aforementioned approaches, to a large extent, understood culture mainly as bounded, fixed and devoid of history and politics, and thus performance - as a "cultural" process and practice - was also largely conceptualised as such. Only with the emergence of critical and transnational anthropology in the 1990s (Appadurai 1996; Fabian 1990; Scott 1985; Stoller 1995), and with multi-sited fieldwork (Marcus 1998), did anthropologists begin accounting for performance and its performativity in relation to power, hybridity, dialogism and reflexivity (Bakhtin 1981; Fabian 1990; Herzfeld 2001; Korom 2013; Kraidy 2005; Ruby 1982; Stoller 1995; Tedlock 1987). Many critical anthropologists have looked to the work of Michel Foucault (1977, 1979, 1980, 1984, 1993) to articulate the significance of ritual and performance as key components in the construction of domination and counter-hegemony. Johannes Fabian (1990), for example, holds that performance can become an important means of exploring the illusive, circulating and shifting concept of power. Most importantly for Fabian, performance can illuminate the nature of power enacted by specific individuals on a specific occasion, because "the people who perform relate to each other and their society at large in terms of power" (17).

Most recently, anthropologists have extended this understanding of the performativity of performance by paying attention to the ways that performance constitutes and is constitutive of globalising forces, processes of commodification and transnational interventions (Korom 2013, 5). Deborah Kapchan $(2013,217)$, for example, examines how performance - music festivals, specifically - "create transnational communities of affect" through "sacred tourism." A recent volume, Dancing Cultures: Globalization, Tourism and Identity in the Anthropology of Dance, edited by Hélène Neveu Kringelbach and Jonathan Skinner (2012, 9), also explores, through a wide range of case studies, the agency of "flows and movements of dance" vis-à-vis nationalism, globalisation, post-colonialism and capitalism.

But what is it specifically about performance employed as ethnography that might contribute to the anthropological study of imagination? Is it its quality of emergence - the fluid and improvisational processes of its making and remaking in and through the interactions among performers and audiences - that might prove particularly useful here? Yet, how would that make performance different from other ethnographic methods? Ethnography and fieldwork, after all, have also come to be viewed as performance and as performative in their own right. Dennis Tedlock (1987) notes that ethnography is a form of interpretive dialogic performance for an audience of fellow co-performers, including the ethnographer. Fabian (1990) also sees ethnography as co-performative, as the ethnographer acts as a co-performer, rather than inquisitor, in the dialogic construction of knowledge. More recently, Quetzil Castañeda (2006) has drawn on Brazilian theatre director Augusto Boal's idea of invisible theatre, an approach of his Theatre of the Oppressed, in which actors put on an improvised performance in a public space without disclosing it as a performance in order to engage people in a debate of polemical issues. Castañeda (2006) argues that fieldwork, although made explicit to interlocutors, is also, fundamentally, a form of invisible theatre, because as researchers, we constantly question whether our fieldwork practices constitute research: ethnographers and interlocutors are both actors and spectators, each respectively "acting" and "observing" in the contexts of both their everyday lives and fieldwork (81); our interlocutors' agendas may remain invisible to us (82); and fieldwork is quintessentially improvisational (82). Allaine Cerwonka and Liisa Malkki (2007) also articulate the idea of fieldwork as improvisation by foregrounding its unpredictability, which forces us to perpetually respond to the shifting and changing contexts around us.

\section{Ethnography, Performance and Imagination}

The contributors to this thematic section suggest that it is the particular ways performance sets up the conditions for the production of ethnographic knowledge - or what Andrew Irving calls a particular performative context of address - that render it especially useful in the anthropological study of imagination and as an imaginative ethnographic method. Some of the ways that performance crafts this particular context of address include the following: mutual interactions between and among performers, the ethnographer and the audience; its interplay of dramatic text, speech, action, the body, image and sound; its collective (but not necessarily collaborative) nature, requiring the engaged participation of multiple parties; with more traditionally theatrical performances, a subjunctive encounter, where the performer acts as if they were the character portrayed; and, additionally, the use of fiction. In the past few decades, research that has come to be known as performance ethnography (or, alternatively, ethnographic theatre, performative ethnography and ethnodrama) has explored the potential 
of these performative conditions for the construction of ethnographic knowledge.

Performance ethnography dates back to the collaboration between anthropologists Victor and Edith Turner and performance studies scholar Richard Schechner in the 1970s and the early 1980s, a time when the anthropological focus had begun shifting from function to process and from structure to performance. The performance ethnography experimentations by the Turners and Schechner employed "instructional theatre" (Turner 1982, 41), a means of representing fieldwork data to primarily academic audiences in order to facilitate a "kinetic" learning process about the ways of life in another culture (Schechner 1985; Turner and Turner 1982, 34). With the crisis of representation, blurred genres and performative turns that beset anthropology and other disciplines, subsequent approaches have also focused on performance as a means of representing and communicating ethnographic research (Denzin 2003; Goldstein 2010; Mienczakowski 1992, 1994, 1995, 2000, 2001; Saldaña 2003, 2005; Schechner 1985; Turner and Turner 1982); as a form of ethnographic participant observation in which the ethnographer poses research questions by developing a performance - or staging a performative event - in collaboration with research participants (Conquergood 1988, 2002; Culhane 2011; Fabian 1990; Irving 2011; Kazubowski-Houston 2010, 2011a, 2011b; Madison 2010; Pratt and Kirby 2003); and as an autoethnographic research method for studying the social (Corey 1996; Denzin 2003; Gingerich-Philbrook 2005; Kogut 2005; MacDonald 2012; Scott 2013; Spry 2001). ${ }^{1}$ These scholars have studied performance as a participatory, collaborative, dialogic, intersubjective and empowering approach to ethnography, and one that may politicise the participants, the ethnographer and audience members by engaging them empathically and critically in the issues presented. Here, some draw on German theatre director and theoretician Bertolt Brecht's (1964) theory of epic theatre, which holds that the politicising potential of theatre lies in its ability to inspire social critique and action in audience members, or on the notion that performance can instigate an intersubjective process of self-reflection and self-discovery in performers/research participants, because those who perform always evaluate their performances in relation to fellow performers and audience responses (Palmer and Jankowiak 1996).

More recently, the study of embodiment, the senses and affect has also opened new doors to thinking about how performance could contribute to anthropological research. Interdisciplinary affect theory (e.g., Ahmed 2004; Clough and Halley 2007; Cvetkovich 2003, 2012; Gregg and Seigworth 2010; Massumi 2002; Stewart 2007; Thrift
2003) stresses the importance of conducting research that engages not only observation but also the senses and corporeal means of knowing (Classen 1991, 1998, 2012; Herzfeld 2008; Howes 1991; MacDougall 2005, 2009; Massumi 2002; Pink 2004; Sterne 2012; Stoller 1989, 1997; van Ede 2007). Anthropologists of embodiment employ a variety of approaches and methodologies that bridge ethnography, anthropology and the creative arts to facilitate a construction of ethnographic knowledge through the use of movement and gesture, image, symbol, metaphor, sound, touch and smell. Drawing on these experimentations, performance ethnography scholars suggest that performance can contribute to ethnography by offering an embodied, affective, metaphoric, physical and visual means of expression (Conquergood 2002; Denzin 2003; Fabian 1990; Irving 2011; Kazubowski-Houston 2010, 2011b; Madison 2005; Magnat 2012).

Dance studies is a field that has much to offer to researchers investigating the interrelation of ethnography, performance, embodiment, sensory perception and imagination, as exemplified by dance ethnography. In The Routledge Dance Studies Reader, Theresa Jill Buckland $(2010,325)$ traces the emergence of dance ethnography to the integration of anthropological participant observation, envisioned by dance ethnographers as "a quest to understand and communicate the emic, that is, the insider, perspective of the participants." A shift from dance as a cultural product to dance as an experiential process occurred under the influence of the postmodern turn in the social sciences, compelling dance ethnography to investigate "the emergent performance of cultural identities that are non-essential, fluid and relational" (Buckland 2010, 337). Feminism, postmodern anthropology and performance studies have significantly shaped dance ethnography, whose focus on the body critically informs ethnographic practice, considered to be necessarily grounded in embodied experience (Buckland 2006, 8).

Since the 1990 s, dance ethnographers have prioritised the methodology of embodied practice that requires researchers to gain movement competence in the dance practices being researched, an approach positing "the 'I' persona as a source, dancing and reflecting on sensation and meaning," thereby opening possibilities for the exploration of embodied cultural knowledge that is temporarily and spatially dynamic, situational, and often related to expressions of identity (Buckland 2006, 13-14). Moreover, by combining history and ethnography in Dancing from Past to Present, Buckland $(2006,17)$ is able to track "acts of selection, omission, exclusion, transformation, and creation" in the embodied production of cultural memory and account for the impact of colonialism, nationalism and globalisation on transmission 
processes and cultural continuity. This interdisciplinary approach to dance studies hence provides important insights into the role of embodied creativity and imagination in performances of cultural identity and community.

In an essay in Fields in Motion: Ethnography in the Worlds of Dance, Karen Barbour (2011, 118), whose research draws from feminism and phenomenology, suggests that autoethnography can stimulate kinaesthetic empathy through "thick descriptions, texture, flow, and resonance." She writes about the environmentally responsive approach to dance-making that entails developing a heightened awareness of one's surroundings "to allow sounds, smells, visual stimuli, and sensations from the natural world to be cues for movement-improvisation" (126). In the same volume, Janet Goodridge (2011, 137) considers the body to constitute a living archive, and she employs movement-based improvisation to explore change, impermanence and unexpectedness in human and natural life, relating the movement of "clouds, winds in trees - across grasses; shifting weather" to that of human beings, who are "constantly in physical flux and must adapt to changing circumstances in daily life." Her embodied research provides insights into the relationship between movement and spontaneity, "a key ingredient in the play of imagination, in surprise and humour - spontaneity is present in the response to the unforeseen" (137). She specifies that spontaneity in movement is related to the notion of free flow in Labanotation, a type of unrestricted fluidity that is "inherent in the poetic imagination" (138). In their dance ethnographies, Buckland, Barbour and Goodridge refer to embodied forms of awareness, sensitivity, creativity, spontaneity and imagination that are relevant to the performative and improvisational dimensions of fieldwork, since most ethnographers engage in spatially and temporally situated human interactions that are always in flux and unpredictable. As Helen Thomas $(2003,215)$ points out, "the ethnographic field is an embodied field and yet few ethnographers outside of dance studies have explored this aspect in any depth."

Indeed, performance ethnography explorations within the discipline of anthropology have, for the most part, been conducted primarily at the representational level, using performance to stage interview transcripts, field notes and journal entries in order to communicate research findings through embodied and sensory ways to diverse academic and non-academic audiences; as pedagogical strategies in the classroom; or to facilitate social critique and interventions in engaged, applied and activist research. Methodological experimentations involving the ethnographic process itself have remained rare. In anthropology, Fabian (1990) was a precursor to the previously mentioned approach that employs performance as a form of ethnographic participant observation. Other performance ethnography methodological explorations have involved employing performance as ethnographic participant observation in the study of power within the ethnographic process itself (Kazubowski-Houston 2010); as utopian improvisational ethnography for exploring ethical engagements between the ethnographer and research participants (Culhane 2011); as collaborative and ethnographic community engagement in political and social commentary (Papa and Lassiter 2003); and as an embodied way of knowing that is pivotal to the decolonising research methodologies developed by Indigenous scholars (Magnat 2012).

The articles in this thematic section are concerned with performative experimentations at the level of ethnographic process while at the same time addressing questions of performance as representation. However, the contributors extend this approach by placing imagination squarely at the centre of inquiry.

In his contribution, Andrew Irving discusses collaborative visual ethnography as a means of constructing ethnographic knowledge about how people affected by illness imagine and understand the contingencies and necessities of life and death. His research in Kampala, Uganda, engaged two teenage brothers in a process of making an ethnographic film about how HIV/AIDS and loss have affected their family over the course of 20 years, throwing into sharp relief the stark contrast between the lives the participants lived and those they could have lived. Irving argues that performing for the camera - which sets up a particular form of performative address, creating new relationships, forms of interactions and contexts for the production of experience, memory and knowledge - can provide insights into people's inchoate imaginative lifeworlds, which are important constituents of their lived experiences but frequently remain unexpressed. His article forges new trajectories for the anthropology of imagination by articulating how performance might help us account for the forces of contingency and necessity. For Irving, engaging research participants directly in filming, performing and reflecting on the entire creative process provides an opportunity for collaborative fieldwork that addresses issues relevant to people's everyday lives, rather than abstract concerns. Such a collaborative process of film-making can, in turn, potentially constitute an imaginative engaged and interventionist anthropology by inviting an ethical awareness of the lives of those deeply affected by the history of colonialism and global market capitalism. For Irving, such a sharing of life through film-making that ventures out into the world might constitute an important strategy of protecting the 
rights of others. Finally, Irving's article itself experiments with performative modes of scholarly representation by including, in addition to a written account, an accompanying photo essay composed of screen grabs.

Johannes Sjöberg's contribution focuses on roleplaying as an anthropological approach and ethnographic research methodology in the study of imagination in different fieldwork contexts, including his practice-based research on intolerance and abuse suffered by transgendered Brazilians in São Paulo. His research has resulted in an ethnofiction - an ethnographic film that incorporates elements of fiction - entitled Transfiction (2007), as well as performative experimentations in the anthropological study of the future at the Future Anthropology Network's laboratories that he co-organised at the European Association of Social Anthropologists (EASA) conferences in Tallinn (2014) and in Milan (2016). By role play, Sjöberg means a form of play in which participants improvise for a video camera "as if they were themselves, but without any obligation to really be themselves" (406). In such a projective improvisation, it is provocation, pleasure and flow that motivate the performance, constituting a form of epistemology. Most importantly, however, as a liminal space of in-between, role play, according to Sjöberg, has the potential to transcend reality and, through the use of mimicry, provide fieldwork participants with an opportunity to perform in their own imaginary worlds while simultaneously drawing on their everyday realities. For Sjöberg, role play can be either descriptive, seeking to represent events otherwise difficult to convey - for example, when his transgendered participants in Brazil improvised illegal practices, such as silicone breast injections - or expressive, facilitating reflection upon issues relevant to one's personal life such as when his participant, Fabia, used improvisations to ruminate on her painful childhood experiences. For Sjöberg, role play is a valid ethnographic research method in the study of imagination because it makes participants' implicit imaginative worlds explicit. His analysis demonstrates that role play can offer a highly collaborative, participatory, reflexive and interventionist form of ethnography. It is a collaborative ethnography or what Sjöberg prefers to call negotiation, a term that acknowledges the conflict inherent in fieldwork - because it invites participants and the ethnographer to coconstruct and co-reflect upon cultural meanings through play that blends reality and fantasy. His approach to role play can be viewed as an engaged and interventionist anthropology because it affords participants a space wherein they can explore, through the characters they create, their own identities and discuss issues they would not normally discuss.
Magdalena Kazubowski-Houston, drawing on trail anthropology and on Russian theatre artist Constantin Stanislavski's notion of the through-line of action, tracks the feeling of awkwardness she experienced in an imaginative ethnography project she conducted in collaboration with an elderly Polish Roma woman, Randia, in an attempt to re-envision anthropology as an engaged, collaborative and interventionist practice. The project employed dramatic storytelling as an anthropological approach and ethnographic method to study Roma women's experiences of aging following the recent mass migrations of Polish Roma to Western Europe. In dramatic storytelling sessions, Randia - adopting a variety of acting styles that ranged from psychological realism (where the actor emotionally identifies with her character), epic theatre (where the actor portrays rather than identifies with her character) and magic realism (which incorporates both real and fantastical elements) - created dramatic scenes loosely based on her own life. The dramatic storytelling sessions facilitated a fictional space wherein Randia was able to employ imagination to re-envision different realities, possibilities and futures, thereby serving as catalysts in the making of what Kazubowski-Houston calls an awkward reflexivity that shifted reflexivity from the purview of the anthropologist to that of the interlocutor. The confidentiality and anonymity of fictional storytelling, in mitigating the politics of representation, ensured that Randia was able to say and ask whatever she pleased. The co-performing nature of the storytelling, where the interlocutor and the ethnographer became both spectator and actors ("spect-actors"; see Boal 1979), inspired Randia to make reflexivity the driving force of the sessions and, ultimately, take control over them. For Kazubowski-Houston, creative research approaches and methods, such as dramatic storytelling, can be important in the anthropological study of imagination, as they can help in tapping into and bringing to the surface the subconscious and unacknowledged thoughts and feelings where substantial parts of people's imaginaries dwell. For her, igniting people's imaginations to attend to the diverse, multi-faceted and unpredictable possibilities of everyday life may be an important step toward ethnographic research as interventionist practice.

Denise Nuttall, drawing on her ethnographic participant fieldwork with North Indian (Hindustani) tabla players in India and in North America, and on her reflections as a teacher of tabla, argues that performance should become central to anthropological study. She suggests that since how we learn anthropologically comes by the performance(s) of the body, our engagement with performance must not only be limited to the study of performance as a form of cultural expression 
but should constitute a central theoretical, analytical and methodological framework. In her view, performance as an analytical lens has, unfortunately, been relegated to the periphery in anthropology, while in other disciplines and fields it has moved to the centre. What Nuttall is suggesting here is that, as anthropologists, we should start discussing our ethnographic processes in terms of performance rather than exclusively focusing on fieldwork as experience. Following Michael Jackson (2009), she argues that more conventional forms of participant observation are insufficient for research that seriously engages with non-western epistemologies and theologies. Ultimately, building on recent scholarship in the anthropology of music, ethnomusicology, the anthropology of sound and performance ethnography, her article calls for anthropologists to adopt "the radically empirical" in their work (427), a concept coined by William James and developed further by Jackson (1989) and others to describe the practice of co-inhabiting intersubjective space with others. Nuttall argues that anthropologists are performing ethnographers engaged in various fields of ethnographic inquiry, and, as such, they should focus their "attention on how the radically empirical is indeed embodied" (430). This, according to Nuttall, can only happen if we begin accounting for the everyday performances of the ethnographer while researching in the field, writing up our research findings, and teaching our students. Adopting the radically empirical, Nuttall suggests, is key for anthropology to revitalise itself as an ethical and relevant discipline, as well as to reclaim ethnography as its central and defining methodology at a time when it is being adopted and practised by other disciplines and fields. For Nuttall, performance ultimately offers a more embodied, engaged, sensory and kinesthetic way of conducting ethnographic research, attentive to both insider and outsider perspectives.

Virginie Magnat situates her performative ethnography of cultural resurgence in Occitania at the intersection of anthropology, ethnomusicology, sociology and performance studies. Magnat positions herself as an artist-scholar engaged in (re)learning traditional songs in the critically endangered Occitan language of her Mediterranean cultural heritage. Emphasising the politically charged context of Occitan cultural revitalisation, she historicises the French state's systematic suppression of regional linguistic and cultural practices through the imposition of French as the official language of the public school system in service of a monocultural conception of national identity rooted in France's colonial legacy. She foregrounds the intercultural dimension of the Occitan tradition, which can be traced to the vocal music practices of the troubadours, whose celebrated lyric poetry reflects the vibrant convergence of Muslim, Jewish and Christian world views. In the lineage of critical ethnography, an approach developed during the American Civil Rights Movement and later integrated into performance studies, Magnat asserts that reclaiming this contested intangible cultural heritage through performance constitutes a radical way of reimagining tradition that supports diversity, inclusivity and solidarity, thereby producing a "performance of possibilities" (Madison 2012, 190) that offers a powerful counter-narrative to exclusionary constructions of cultural identity currently fuelled by the disturbing rise of fascist political discourse in Europe and, most recently, North America.

As a companion piece to this thematic section, Kazubowski-Houston and Magnat conducted an interview with Soyini D. Madison. During this stimulating conversation, the author of Critical Ethnography: Method, Eth$i c s$, and Performance relates engaged and imaginative ethnographic fieldwork to what she defines as the ethics of attention. According to Madison, this ethical stance requires us to attend to the fullness of the moment so that we may learn to be fully present in a form of heightened awareness whose sensory and affective dimensions are reminiscent of performance training; referring to the evocative lyrics of a song performed by Dianne Reeves, Madison suggests that practising ethical imaginative ethnography entails being still, keeping quiet, standing in love and paying attention. Of course, one must ask why and how this embodied understanding of the ethnographic process - previously envisioned by Paul Stoller (1997, xvii) as "an opening of one's being to the world - a welcoming" - might make sensory-sensitive research more ethically sound than other methodologies. Sarah Pink acknowledges that the sensory ethnographer is not necessarily "one who cares more," yet she suggests that accounting for the senses in applied research "can lead to an appreciation of what is important in how people feel - the affective and sensory elements of - their social and material worlds" (Pink 2015, 69). For Madison, however, welcoming and appreciation only constitute the first steps toward an imaginative ethnography that engages ethically with our research collaborators' lifeworlds, an ethnographic approach she conceives as a radical political act through which we become witnesses and co-performers of our collective survival. She stresses that embodiment is key in this process, because we learn embodied techniques from the communities we inhabit, and we are connected to others through embodied ways of being and knowing. Madison further contends that when theoretical conceptualisations fail to take embodiment seriously, they become less effective and meaningful. She invokes an imaginative ethnography crucially hinging 
upon embodied, dialogic and intersubjective fieldwork, and combining sensory perception with affective engagement while requiring researchers to account for their positionality through the rigorous practice of reflexivity. Acknowledging the "lazy, quick, insensitive, exploitive, imperialist and colonialist tendencies that rear their ugly heads from time to time in our qualitative or ethnographic methods and analysis" (460), Madison advocates building generously critical alliances with our colleagues and our students. She asserts that ethical rigour includes paying attention to small performative actions that are "filled with consequences and implications" (461), and she encourages imaginative ethnographers to convey in their writing the significance and power of these actions as a way of honouring them. Linking ethics, politics and beauty, she states that "in every circle of resistance and progressive politics, people are making something beautiful," which she believes expresses a shared desire to "negate defeatism" (462). She values the performance of ethnographic text precisely because it can provide access to an embodied experience that requires an emotional investment, a form of visceral engagement that "conjoins text in both [our] bones and brain[s]" (464), thereby creating an opportunity for empathy that materialises through performativity. Anchoring the potentials and promises of imaginative ethnography to its ethical and political imperatives, Madison provocatively foregrounds the figure of the ethnographer-bricoleur as a sensorially and affectively aware activist, whose commitment to transforming fieldwork into responsible vagabondage-qua-resistance urges us to question, contest and unravel the pervasive positivist assumptions underlying dominant research culture in the neoliberal academy.

The contributors to this thematic section each address, in their own ways, the question of why imaginative anthropological approaches and methodologies might be worth engaging in, and what they might contribute to the anthropology of imagination and the anthropological project as a whole. Performance is central to our inquiry because if "it is through performances, whether individual or collective, that humans project images of themselves and the world to their audiences" (Palmer and Jankowiak 1996, 226), then performance needs to be taken seriously in the making and representing of anthropological knowledge. Here, we do not assert that performance employed as an anthropological and ethnographic approach would necessarily or always provide a more collaborative, participatory, reflexive and interventionist way of doing anthropology. Clearly, performance, like any anthropological approach and ethnographic research method, has its own obstacles to tackle, which will always be particular and unique for each different research project. In fact, as KazubowskiHouston (2010, 2011a) has argued elsewhere, performative approaches to research - as they frequently bring individuals, groups and communities together in close working relationships - can be mired by power struggles and politics of representation that thwart their collaborative and interventionist efforts. However, as this thematic section demonstrates, in offering a different form of performative address, performance can put forth an alternative way of conducting ethnography, doing analysis and communicating research findings that might be particularly suitable in the anthropological study of messy, shifting and incidental imaginings as they emerge in the present. As such, when combined with more conventional or other imaginative approaches and methods, it might constitute an important step toward what Faye Ginsburg $(1995,65)$ called for in the 1990s "a parallax effect" or "different angles of vision" - in the understanding of social life and lived experience. We also hope that this thematic section will spark an imaginative project in itself, spurring readers to re-envision how performance and other creative approaches might further enrich our study of imagination, the ways we do ethnography and how we communicate our findings, especially across disciplinary boundaries and beyond the academy. In particular, we are interested in initiating conversations about how working at the intersections of anthropology, ethnography, performance and imagination could contribute to the emergent analytical frameworks of embodiment, affect, postphenomenology and posthumanism, new materialisms, the Anthropocene, and ethics and morality, forging new directions for anthropological theory and practice.

Magdalena Kazubowski-Houston, Associate Professor, Department of Theatre, York University, Toronto, ON. Email:mkazubow@yorku.ca.

Virginie Magnat, Associate Professor, Faculty of Creative and Critical Studies, University of British Columbia, Okanagan Campus, Kelowna, BC. Email: virginie.magnat@ubc.ca.

\section{Note}

1 In Canada, performance ethnography gained currency in a variety of fields, including education (Gallagher 2007; Goldstein 2010), sociology (Cavanagh 2013), theatre and performance studies (Bennett 2012; MacDonald 2012; Magnat 2011), health research (Pratt and Kirby 2003) and anthropology (Culhane 2011; Kazubowski-Houston 2010, 2011a, 2011b, 2012, 2017b). 


\section{References}

Ahmed, Sarah. 2004. The Cultural Politics of Emotion. New York: Routledge.

Anderson, Benedict. 1983. Imagined Communities: Reflections on the Origin and Spread of Nationalism. London: Verso.

Appadurai, Arjun. 1996. Modernity at Large: Cultural Dimensions of Globalization. Minneapolis: University of Minnesota Press.

Austin, John L. 1962. How to Do Things with Words. Oxford: Clarendon.

Bakhtin, Mikhail. 1981. The Dialogical Imagination: Four Essays, edited by M. Holquist; translated by M. C. Emerson and M. Holquist. Austin: University of Texas Press.

Barbour, Karen. 2011. "Writing, Dancing, Embodied Knowing: Autoethnographic Research.” In Fields in Motion: Ethnography in the Worlds of Dance, ed. D. Davida, 101-107. Waterloo, ON: Wilfred Laurier University Press.

Bauman, Richard, and Joel Sherzer. 1974. Explorations in the Ethnography of Speaking. New York: Cambridge University Press.

Ben-Amos, Dan, and Kenneth S. Goldstein (eds). 1975. Folklore: Performance and Communication. The Hague: Mouton.

Bennet, Melanie. 2012. "Garden/Suburbia. Mapping the Non-Aristocratic in Lawrence Park." Canadian Theatre Review 151: 44-49. https://doi.org/10.1353/ctr.2012.0062.

Boal, Augusto. 1979. Theatre of the Oppressed, translated by Charles A. McBride, M.O. Leal and E. Fryer. London: Pluto.

Brecht, Bertolt. 1964. Brecht on Theatre: The Development of an Aesthetic, translated by J. Willett. New York: Hill and Wang.

Buckland, Theresa Jill. 2006. Dancing from Past to Present. Madison: University of Wisconsin Press.

_. 2010. "Shifting Perspectives on Dance Ethnography." In The Routledge Dance Studies Reader, ed. J. Giersdorf, Y. Wong and J. O'Shea, 335-343. London: Routledge.

Butler, Judith. 1990. Gender Trouble. London: Routledge. —. 1995. "Burning Acts - Injurious Speech." In Performativity and Performance, ed. A. Parker and E. Kosofsky Sedgwick, 197-227. London: Routledge.

Castañeda, Quetzil. 2006. "The Invisible Theatre of Ethnography: Performative Principles of Fieldwork. Social Thought and Commentary." Anthropological Quarterly 79(1): 75-104. https://doi.org/10.1353/anq.2006.0004.

Cavanagh, Sheila L. 2013. "Affect, Performance, and Ethnographic Methods in Queer Bathroom Monologues." Text and Performance Quarterly 33(4): 286-307. https:// doi.org/10.1080/10462937.2013.823513.

Cerwonka, Allaine, and Liisa H. Malkki. 2007. Improvising Theory: Process and Temporality in Ethnographic Fieldwork. Chicago: University of Chicago Press.

Classen, Constance. 1991. "Creation by Sound/Creation by Light: A Sensory Analysis of Two South American Cosmologies." In Varieties of Sensory Experience: A Sourcebook in the Anthropology of the Senses, ed. D. Howes, 257-288. Toronto: University of Toronto Press.
1998. Worlds of Sense: Exploring the Senses in History and across Cultures. London: Routledge.

- 2012. The Deepest Sense: A Cultural History of Touch. Chicago: University of Illinois Press.

Clough, Patricia Ticineto, and Jean Halley (eds). 2007. The Affective Turn: Theorizing the Social. Durham, NC: Duke University Press.

Comaroff, John L., and Jean Comaroff. 1999. Civil Society and the Political Imagination in Africa: Critical Perspectives. Chicago: University of Chicago Press.

Conquergood, Dwight. 1988. "Health Theatre in a Hmong Refugee Camp: Performance, Communication, and Culture." Drama Review - A Journal of Performance Studies 32(3): 174-208. https://doi.org/10.2307/1145914.

_. 2002. "Performance Studies: Interventions and Radical Research." Drama Review - A Journal of Performance Studies 46(2): 145-156. https://doi. org/10.1162/105420402320980550.

Corey, Frederick C. 1996. "Performing Sexualities in an Irish Pub." Text and Performance Quarterly 16(2): 146-160. https://doi.org/10.1080/10462939609366141.

Crapanzano, Vincent. 2004. Imaginative Horizons: An Essay in Literary-Philosophical Anthropology. Chicago: University of Chicago Press.

Csordas, Thomas. 1994. "Introduction: The Body as Representation and Being-in-the World." In Embodiment and Experience: The Existential Ground of Culture and Self, ed. T. Csordas, 1-26. Cambridge: Cambridge University Press.

Culhane, Dara. 2011. "Stories and Plays: Ethnography, Performance and Ethical Engagements." Anthropologica 53(2): 257-274. https://www.jstor.org/stable/41473878.

Cvetkovich, Ann. 2003. An Archive of Feelings: Trauma, Sexuality, and Lesbian Public Cultures. Durham, NC: Duke University Press.

. 2012. Depression: A Public Feeling. Durham, NC: Duke University Press.

Denzin, Norman K. 2003. Performance Ethnography: Critical Pedagogy and the Politics of Culture. Thousand Oaks, CA: Sage.

Durkheim, Emile. 1965 [1915]. The Elementary Forms of the Religious Life. New York: Free Press.

Elliott, Denielle, and Dara Culhane. 2017. A Different Kind of Ethnography: Imaginative Practices and Creative Methodologies. Toronto: University of Toronto Press.

Fabian, Johannes. 1990. Power and Performance: Ethnographic Explorations through Proverbial Wisdom and Theater in Shaba, Zaire. Madison: University of Wisconsin Press.

Foucault, Michel. 1977. Discipline and Punish: The Birth of the Prison. London: Penguin.

—. 1979. The History of Sexuality, Vol 1. London: Penguin.

- 1980. Power/Knowledge: Selected Interviews and Other Writings, 1972-197\%, edited by C. Gordon. New York: Pantheon.

— 1984. The Foucault Reader, edited by P. Rabinow. New York: Pantheon.

- 1993. The Archaeology of Knowledge. New York: Barnes and Noble. 
Friedrich, Paul. 2007. "Imagination Theory and the Imaginative Act." Irish Journal of Anthropology 10(2): 10-19.

Gallagher, Kathleen. 2007. The Theatre of Urban: Youth and Schooling in Dangerous Times. Toronto: University of Toronto Press.

Geertz, Clifford. 1973. The Interpretation of Cultures. New York: Basic Books.

Gennep, Arnold van. 1960. The Rites of Passage. Chicago: University of Chicago Press.

Gingerich-Philbrook, Craig. 2005. "Autoethnography's Family Values: Easy Access to Compulsory Experience." Text and Performance Quarterly 25(4): 297-314. https://doi. org/10.1080/10462930500362445.

Ginsburg, Faye. 1995. "The Parallax Effect: The Impact of Aboriginal Media on Ethnographic Film.” Visual Anthropology Review 11(3): 64-76. https://doi.org/10.1525/ var.1995.11.2.64.

Goffman, Erving. 1959. Presentation of Self in Everyday Life. New York: Random House.

Goldstein, Tara. 2010. "Snakes and Ladders: A Performed Ethnography." International Journal of Curriculum and Pedagogy 3(1): 68-113.

Goodridge, Janet. 2011. "The Body as a Living Archive of Dance/Movement." In Fields in Motion: Ethnography in the Worlds of Dance, ed. D. Davida, 119-145. Waterloo, ON: Wilfrid Laurier University Press.

Gregg, Melissa, and Gregory J. Seigworth. 2010. The Affect Theory Reader. Durham, NC: Duke University Press.

Hastrup, Kirsten. 2007. "Playing One's Part: The Imaginative Framework of Agency." Irish Journal of Anthropology 10(2): 26-34.

Herzfeld, Michael. 2001. "Performing Comparisons: Ethnography, Globetrotting, and the Spaces of Social Knowledge." Journal of Anthropological Research 57(3): 259-276. https://doi.org/10.1086/jar.57.3.3631423.

—. 2008. "Senses." In Ethnographic Fieldwork: An Anthropological Reader, ed. Antonius C.G.M. Robben and Jeffrey A. Sluka, 422-431. London: Blackwell.

Hogan, Susan, and Sarah Pink. 2010. "Routes to Interiorities: Art Therapy and Knowing in Anthropology." Visual Studies 23(2): 158-174. https://doi. org/10.1080/08949460903475625.

Howes, David (ed.). 1991. The Varieties of Sensory Experience: A Sourcebook in the Anthropology of the Senses. Toronto: University of Toronto Press.

Hymes, Dell. 1964. "Introduction: Toward Ethnographies of Communication." American Anthropologist 66(6): 1-34. https://doi.org/10.1525/aa.1964.66.suppl_3.02a00010.

— 1975. "Breakthrough into Performance." In Folklore: Performance and Communication, ed. D. Ben-Amos and K. S. Goldstein, 11-75. The Hague: Mouton.

Irving, Andrew. 2011. "Strange Distance: Towards an Anthropology of Interior Dialogue." Medical Anthropology Quarterly 25(1): 22-44. https://doi. org/10.1111/j.1548-1387.2010.01133.x.

Jackson, Michael. 1989. Paths Toward a Clearing: Radical Empiricism and Ethnographic Inquiry. Bloomington: Indiana University Press.

_. 2009. "Ethnographic Verisimilitude." Etnofoor; Writing Culture 21(1): 9-19. http://www.jstor.org/ stable/25758147.
Kapchan, Deborah A. 2013. "The Promise of Sonic Translation: Performing the Festive Sacred in Morocco." In The Anthropology of Performance: A Reader, ed. F. J. Korom, 1-7. West Sussex: Wiley.

Kazubowski-Houston, Magdalena. 2010. Staging Strife: Lessons from Performing Ethnography with Polish Roma Women. Montreal and Kingston: McGill-Queen's University Press.

_ 2011a. “'Don’t Tell Me How to Dance!' Negotiating Collaboration, Empowerment and Politicization in the Ethnographic Theatre Project 'Hope."' Anthropologica 53(2): 229-243. https://www.jstor.org/stable/41473876.

- 2011b. "Thwarting Binarisms: Performing Racism in Postsocialist Poland." Text and Performance Quarterly 31(2): 69-89. https://doi.org/10.1080/10462937.2011.552118.

. 2012. “'A Stroll in Heavy Boots': Studying Polish Roma Women's Experiences of Aging." Canadian Theatre Review 151: 16-23. https://doi.org/10.3138/ctr.151.16.

_ 2017a. "Agency and Dramatic Storytelling: Roving through Pasts, Presents, and Futures.” In Anthropologies and Futures: Researching Emergent and Uncertain Worlds, ed. J. F. Salazar, S. Pink, A. Irving and J. Sjöberg, 209-224. London: Bloomsbury Academic.

— 2017b. "Performing." In A Different Kind of Ethnography: Imaginative Practices and Creative Methodologies, ed. D. Elliott and D. Culhane, 113-133. Toronto: University of Toronto Press.

Kogut, Kate B. 2005. "Framed: A Personal Narrative/ Ethnographic Performance/One-Woman Show.” Journal of American Folklore 118(467): 90-104. https://doi. org/10.1353/jaf.2005.0004.

Korom, Frank J. 2013. "The Anthropology of Performance: An Introduction." In The Anthropology of Performance: A Reader, ed. F. J. Korom, 1-7. West Sussex: Wiley.

Kraidy, Marwan M. 2005. Hybridity: The Cultural Logic of Globalization. Philadelphia: University of Pennsylvania Press.

Kumar, Anita. 2013. "The Play Is Now Reality: Affective Turns, Narrative Struggles, and Theorizing Emotion as Practical Experience." Culture, Medicine and Psychiatry 37(4): 711-736. https://doi.org/10.1007/s11013-013-9333-z.

Lord, Albert. 2000. The Singer of Tales. 2nd edition. Cambridge, MA: Harvard University Press.

MacDonald, Shauna M. 2012. "Staging and Storying Blood from a Stone: A Performative Reflection in Three Acts." Canadian Theatre Review 151: 37-43. https://doi. org/10.1353/ctr.2012.0060.

MacDougall, David. 2005. The Corporeal Image: Film, Ethnography, and the Senses. Princeton, NJ: Princeton University Press.

- 2009. "Anthropology and the Cinematic Imagination." In Photography, Anthropology and History, ed. C. Morton and E. Edwards, 55-65. Burlington, VT: Ashgate.

Madison, D. Soyini. 2005. Critical Ethnography: Method, Ethics, and Performance. Thousand Oaks: Sage.

- 2010. Acts of Activism: Human Rights as Radical Performance. New York: Cambridge University Press.

- 2012. Critical Ethnography: Method, Ethics, and Performance. Thousand Oaks, CA: Sage.

Magnat, Virginie. 2011. "Conducting Embodied Research at the Intersection of Performance Studies, Experimental 
Ethnography and Indigenous Methodologies." Anthropologica 53(2): 229-243. http://www.jstor.org/ stable/41473875.

- 2012. "Can Research Become Ceremony?

Performance Ethnography and Indigenous

Epistemologies." Canadian Theatre Review 151: 30-36. https://doi.org/10.1353/ctr.2012.0058.

Malinowski, Bronislaw. 1948. Magic, Science and Religion and Other Essays. Boston: Beacon.

Marcus, George. 1998. Ethnography through Thick and Thin. Princeton, NJ: Princeton University Press.

Massumi, Brian. 2002. Parables for the Virtual: Movement, Affect, Sensation. Durham, NC: Duke University Press.

Mauss, Marcel (1935) 1973."Techniques of the Body." Economy and Society 2(1): 70-88. https://doi. org $/ 10.1080 / 03085147300000003$.

McLean, Stuart. 2007. "Introduction: Why Imagination?" Irish Journal of Anthropology 10(2): 5-9.

Mienczakowski, Jim. 1992. Syncing Out Loud: A Journey into Illness. Brisbane, Australia: Griffith University.

_. 1994. "Reading and Writing Research." NADIE Journal: International Research Issue 18: 45-54.

- 1995. "The Theatre of Ethnography: The

Reconstruction of Ethnography into Theatre with Emancipatory Potential." Qualitative Inquiry 1: 360-375. https://doi.org/10.1177/107780049500100306.

- 2000. "Ethnography in the Form of Theatre with Emancipatory Intentions." In Research and Inequality, ed. C. Truman, D.M. Mertens and B. Humphries, 126-142. London: UCL Press.

. 2001. "Ethnodrama: Performed Research -

Limitations and Potential." In Handbook of Ethnography, ed. P. Atkinson, A. Coffey, S. Delamont, J. Lofland and L. Lofland, 468-476. London: Sage.

Murray, David. 2016. Real Queer? Sexual Orientation and Gender Identity Refugees in the Canadian Refugee Apparatus. London: Rowman and Littlefield.

Neveu Kringelbach, Hélène N., and Jonathan Skinner (eds). 2012. Dancing Cultures: Globalization, Tourism and Identity in the Anthropology of Dance. New York: Berghan.

Palmer, Gary B., and William R. Jankowiak. 1996. "Performance and Imagination: Toward an Anthropology of the Spectacular and the Mundane." Cultural Anthropology 11(2): 225-258. https://doi.org/10.1525/ can.1996.11.2.02a00040.

Papa, Lee, and Luke Eric Lassiter. 2003. "The Muncie Race Riots of 1967: Representing Community Memory through Public Performance, and Collaborative Ethnography between Faculty, Students, and the Local Community." Journal of Contemporary Ethnography 32(2): 147-166. https://doi.org/10.1177/0891241602250883.

Pink, Sarah. 2004. Home Truths: Gender, Domestic Objects and Everyday Life. London: Berg.

- 2015. Doing Sensory Ethnography. 2nd edition. Thousand Oaks, CA: Sage.

Pratt, Geraldine, and Elia Kirby. 2003. "Performing Nursing: BC Nurses' Union Theatre Project.” ACME: An International E-Journal for Critical Geographies 2(1): 14-31. https://acme-journal.org/index.php/acme/article/ view/705.
Rapport, Nigel, and Joanna Overing. 2000. Social and Cultural Anthropology: The Key Concepts. New York: Routledge.

Robbins, Joel. 2010. "On Imagination and Creation: An Afterword.” Anthropological Forum 20(3): 305-313. https://doi.org/10.1080/00664677.2010.515296.

Ruby, Jay. 1982. Crack in the Mirror: Reflexive Perspectives in Anthropology. Philadelphia: University of Pennsylvania Press.

Saldaña, Johnny. 2003. "Dramatizing Data: A Primer.” Qualitative Inquiry 9(2): 218-236. https://doi. org/10.1177/1077800402250932.

- 2005. Ethnodrama. London: AltaMira.

Schechner, Richard. 1985. Between Theatre and Anthropology. Philadelphia: University of Pennsylvania Press.

Scott, James. 1985. Weapons of the Weak: Everyday Forms of Peasant Resistance. New Haven, CT: Yale University Press.

Scott, Julie-Ann. 2013. "Problematizing a Researcher's Performance of 'Insider Status': An Autoethnography of 'Designer Disabled' Identity." Qualitative Inquiry 19(2): 101-115. https://doi.org/10.1177/1077800412462990.

Sime, Jennifer. 2007. "The Prickly Beards of Shepherds and the Peeled Moon and the Fly ... Locating and Dislocating Lorca's Duende." Irish Journal of Anthropology 10(2): 44-50.

Singer, Milton B. 1961. "Text and Context in the Study of Contemporary Hinduism." Adyar Library Bulletin 25: 274-303.

- 1972. When a Great Tradition Modernizes: An Anthropological Approach to Indian Civilization. New York: Praeger.

Sjöberg, Johannes. 2007. Transfiction. Brazil, Sweden, and UK: FaktaFiktion Sweden and University of Manchester.

Sneath, David, Martin Holbraad, and Morten A. Pederson. 2009. "Technologies of the Imagination: An Introduction.” Ethnos 74(1): 5-30. https://doi. org/10.1080/00141840902751147.

Spry, Tami. 2001. "Performing Autoethnography: An Embodied Methodological Praxis.” Qualitative Inquiry 7(6): 706-732. https://doi.org/10.1177/107780040100700605.

Sterne, Jonathan. 2012. "Sonic Imaginations." In The Sound Studies Reader, ed. J. Sterne, 1-17. London: Routledge.

Stewart, Kathleen. 2007. Ordinary Affects. Durham, NC: Duke University Press.

Stoller, Paul. 1989. The Taste of Ethnographic Things: The Senses in Anthropology. Philadelphia: University of Pennsylvania Press.

— 1995. Embodying Colonial Memories. New York: Routledge.

—. 1997. Sensuous Scholarship. Philadelphia: University of Pennsylvania Press.

Taylor, Charles. 2002. "Modern Social Imaginaries.” Public Culture 14(Special Issue on New Imaginaries): 91-124. https://doi.org/10.1215/08992363-14-1-91.

Tedlock, Dennis. 1987. “Questions Concerning Dialogical Anthropology." Journal of Anthropological Research 43(4): 325-337. https://doi.org/10.1086/jar.43.4.3630541.

Thomas, Helen. 2003. The Body, Dance and Cultural Theory. New York: Palgrave Macmillan.

Thrift, Nigel. 2003. "Performance and. ..." Environment and Planning A 35: 2019-2024. https://doi.org/10.1068/a3543a. 
Turner, Victor. 1967. The Forest of Symbols: Aspects of Ndembu Ritual. Ithaca, NY: Cornell University Press. 1982. From Ritual to Theatre: The Human

Seriousness of Play. New York: PAJ. 1986. "Dewey, Dilthey, and Drama: An Essay in the Anthropology of Experience." In The Anthropology of Experience, ed. V.W. Victor and E.M. Bruner, 33-44. Champaign: University of Illinois Press. PAJ.
Turner, Victor, and Edith Turner. 1982. "Performing Ethnography.” Drama Review 26(2): 33-50. http:/doi. org/10.2307/1145429.

van Ede, Yolanda. 2007. "From the Untouchables towards Cool Investigation." In Wildness and Sensation: An Anthropology of Sinister and Sensuous Realms, ed. R. van Ginkel and A. Strating, 274-294: Amsterdam: Het Spinhuis. 